\title{
Evaluation of Methods of DNA Extraction from Down, and a Quantitative Real-time PCR Assay for Authenticity Control in Down Products
}

\author{
Shan $\mathrm{Wu}^{1,2}$, Huizhen $\mathrm{Yu}^{1}$, Yongqiang $\mathrm{He}^{1,2}$, Mingzhe Zhang ${ }^{1,2}$, Wenxiu Yin ${ }^{1}$, Quan Zhang ${ }^{1}$, Chao Sun ${ }^{1}$, Zhe Chen $^{1,2}$, \\ Xufang Shen ${ }^{1}$, and Xiaofeng Zhang ${ }^{1,2 *}$

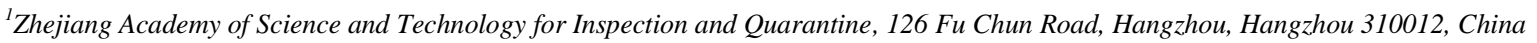 \\ ${ }^{2}$ Technology Center of Hangzhou Customs, 126 Fu Chun Road, Hangzhou, Hangzhou 310012, China \\ *Corresponding author's Email: breezeyh@ @otmail.com; ORCID: 0000-0001-6711-9434
}

Received: 14 October 2021

Accepted: 28 November 2021

\begin{abstract}
Down, mainly duck down and goose down, is one of the most important products in the poultry industry. To improve the accuracy of identification of duck and goose down by quantitative real-time PCR (qPCR), and the efficiency of extracted DNA from down was evaluated and optimized using the template preparation methods, including four pretreatment methods (shredding [PA], shredding + magnetic bead homogenization [PB], shredding + manually grinding in liquid nitrogen [PC], and shredding + grinding by 6875 Freezer [PD]) and three extraction methods (a magnetic bead adsorption method [MA], a membrane adsorption-elution method [MB], and a Chelex® 100 Resin method $[\mathrm{MC}]$ ), and their combinations. The results showed that high-intensity grinding, and grinding in liquid nitrogen can help the improvement of DNA yield, therefore, PB, PC, and PD were superior to PA both in DNA concentration and purity. However, in the subsequent qPCR analysis, the DNA of the highest quantity and purity from PD indicated the lowest positive detection rate. According to the results of the current study, the extraction method had a greater impact on the quality of DNA than the pretreatment method. Although the concentrations and purities of the templates obtained by MA, MB, and MC were varied greatly, all the templates could meet the needs in the following qPCR assay. Furthermore, considering the simplicity of the methods, PA + MC was chosen as the most convenient and efficient combination to extract DNA from down. A quantitative calculation method for the identification of the authenticity of down products was established. Although quantification results could not estimate the target content accurately, they reflected the trend in the content. Nevertheless, the method may be useful as an alternative tool for qualitative and quantitative quality control of the down products.
\end{abstract}

Keywords: Authenticity discrimination, Down, DNA extraction, Quantitative detection, Quantitative PCR

\section{INTRODUCTION}

Duck down and goose down are two main kinds of down products on the market. There is no significant difference in their appearance, but as a natural insulator, goose down is better than duck down, so, the price is also higher than that of ducks. Consequently, the adulteration of duck down or landfowl down in goose down has occurred. In addition to duck and goose down, down also exists in many other forms, such as whole waterfowl feather, broken and damaged waterfowl feather, whole landfowl feather, broken and damaged landfowl feather, plumules, down fibers, feather fibers, quill feathers, and residual matter. The most commonly used method for classification of all types of downs is based on morphological differences, which could be identified using the naked eye or microscopic observation. There are several standards for the classification and determination of the quantitative composition of feather and down, such as the European standard BS-EN-12131: 2018 (2018), the Chinese standards FZ/T 80001-2002 (2002), and GB/T 10288-2016 (2016) that also provide the basis for species identification of downs and feathers. However, since the description in the standards standard is more of a written description, it is difficult for the operator to master morphological identification.

Chen et al. (2013) designed the duck and goose species-specific primer/probe sets to establish the quantitative real-time PCR (qPCR) method for the identification of duck down and goose down. The qPCR method overcomes the subjectivity of the manual method 
and could be chosen as an auxiliary for detection. In this regard, DNA of sufficient yield and quality is the crucial starting material for the qPCR analyses. As Chen et al. (2013) mentioned, although the quality of the DNA could meet the needs of qPCR testing, the method of DNA extraction with sodium dodecyl sulfate (SDS)-guanidine thiocyanate and $\beta$-mercaptoethanol was time-consuming and laborious; and of all the steps, a water bath alone took about 6 hours, and DNA precipitating from alcohol took even a night. Although reports on DNA isolation from down products are rare, there are some studies on DNA extraction from bird feathers (Speller et al., 2011; Boonseub et al., 2012; Presti et al., 2013), animal hair (Subramanian et al., 2005; Alberts et al., 2010; Henry and Russello, 2011), and human hair (Haines and Linacre, 2016; Grisedale et al., 2018). Among the methods, various commercially available DNA extraction kits were a common choice (Tomasek et al., 2008; Boonseub et al., 2012; Presti et al., 2013). In addition, Tris-HCl based lysis method (Bello et al., 2001), simple alkaline extraction method (Malagó et al., 2002), and the Chelex ${ }^{\circledR} 100$ Resin method (Tomasek et al., 2008) were often used as the alternatives. However, in previous studies, the pretreatment processing of the sample before DNA isolation was rare. The current study aimed to adapt and compare a variety of pretreatment methods to investigate the accuracy of qPCR method to identify duck and goose down in addition to the comparison of DNA extraction methods. Finally, an optimum combination of pretreatment procedure and DNA isolation method were presented. Furthermore, taking the advantage of the quantifiable ability of the qPCR method, this study presented a way to calculate the proportion of goose down and duck down or any other landfowl down in the down products, which would be beneficial to quality control.

\section{MATERIAL AND METHODS}

\section{Sample selection and preparation}

The down and feather samples were provided by the Zhejiang Zhongda Technical Import and Export Group Co., Ltd, and the Microbiological Laboratory of Technical Center of Hangzhou Customs. Three samples of Beijing white duck down, Polish white duck down, and Northeast white goose down were chosen for a comparative test on the various pretreatment and DNA extraction methods. To prepare binary species down mixtures (duck down in goose down), Polish white duck down and China Northeast white goose down were used as materials. Six different percentages, $0,10,20,30,40,50 \%(\mathrm{w} / \mathrm{w})$ of duck down were prepared for each duck-goose binary mixture, to a final weight of $1 \mathrm{~g}$.

\section{Pretreatment methods for DNA extraction}

Before DNA extraction, the down was cut as small as possible by scissors, and then the following pretreatments were performed.

\section{Preprocessing A (PA)}

No further pretreatment was followed, and DNA was extracted directly according to the kit.

\section{Preprocessing B $(\boldsymbol{P B})$}

The shredded down with magnetic beads $(\varphi 3 \mathrm{~mm}$; Sigma, USA) was homogenized on a high-throughput bead beating homogenizer (Bertin Precellys Evolution, Bertin Technologies, France) using $5500 \mathrm{r} / \mathrm{min}$ for 20 seconds, and was repeated 4-6 times.

\section{Preprocessing $\boldsymbol{C}(\boldsymbol{P C})$}

The shredded down was manually ground in liquid nitrogen until it was fractured.

\section{Preprocessing $D(P D)$}

The shredded down was ground by 6875 Freezer/Mill@ High Capacity Cryogenic Grinder (SPEX Sample Prep, USA). The procedure started with precooling the instrument and sample for 7 minutes, followed by grounding the sample for 2 minutes at 12 CPS (cycle per second) and cooling the instrument and sample again for 2 minutes. After the pretreatment, $50 \mathrm{mg}$ material was taken from each sample for DNA isolation by Wizard Magnetic DNA Purification System for Food (FF3750, Promega, USA) according to the manufacturer's instructions. Finally, the DNA was dissolved in $50 \mu \mathrm{L}$ $\mathrm{H}_{2} \mathrm{O}$.

\section{DNA extraction methods}

An ideal method was selected as a unified preprocessing method from the four pretreatments of A, B, $\mathrm{C}$, and D by comparing DNA yield, purity, and the results of qPCR. Based on it, in the following test, the effects of three different DNA extraction methods were compared.

\section{Method A}

Method A (MA) involved Wizard Magnetic DNA Purification System for Food (FF3750, Promega Corporation, USA) extraction kit. This DNA purification kit uses the magnetic beads adsorption method for DNA isolation. For each extraction test, $50 \mathrm{mg}$ of down sample was used. Finally, DNA was dissolved in $50 \mu \mathrm{L}$ water. The whole process took 1.5 to 2 hours.

\section{Method B}

In Method B (MB), QIAamp DNA Mini Kit (50) (51304, QIAGEN GmbH, Germany) was used. It's a silica 
membrane column-based DNA purification system. For each test, $25 \mathrm{mg}$ of sample was used. DNA was dissolved in $25 \mu \mathrm{L}$ water. Including 3 hours of incubation for complete lysis. The process took about 4.5 hours.

\section{Method C}

Chelex® 100 Resin (Sigma, USA) method was used in method $\mathrm{C}$ (MC). A $50 \mathrm{mg}$ sample was added to the microcentrifuge tube and $500 \mu \mathrm{L} 5 \%$ w/v Chelex ${ }^{\circledR} 100$ Resin and $10 \mu \mathrm{L} 10 \mathrm{mg} / \mathrm{mL}$ proteinase $\mathrm{K}$ (TaKaRa, Dalian, China) pipetted into the tube. Then, the tube was incubated for 30 minutes at $56^{\circ} \mathrm{C}$ followed by a 15 minutes incubation at $99^{\circ} \mathrm{C}$. After cooling, the sample was vortexed briefly and centrifuged at $20000 \times \mathrm{g}$ for 10 minutes. The supernatant was used as the DNA sample in the following test. The process took about 1 hour.

\section{DNA quality assessment}

DNA concentrations were measured spectrophotometrically by $\mathrm{A}_{260} \mathrm{~nm}$ of NanoDrop ND-1000 (Thermo Fisher Scientific, Waltham, MA, USA). The purity was assessed by measuring the ratio of absorbance at $260 \mathrm{~nm}$ and $280 \mathrm{~nm}$, respectively. $\mathrm{A}_{260 / 280}$ is a relative absorbance reading, indicating DNA purity, and should ideally be 1.8 for most molecular biology applications. In addition, the DNA quality was also assessed by the downstream fluorescence PCR. All DNA isolation and qPCR experiments were repeated at least three times.

\section{Real-time PCR amplification}

The duck, goose, and chicken species-specific qPCRs were carried out according to a Chinese trade standard SB/T 10923-2012 (2013). The primers and fluorogenic probes used in the qPCR were based on the standard with some modifications (Table 1) and purchased from TaKaRa (Dalian, China). Real-time PCR was performed with an initial denaturation of $95^{\circ} \mathrm{C}$ for 10 seconds, followed by 40 cycles at $95^{\circ} \mathrm{C}$ for 5 seconds and $60^{\circ} \mathrm{C}$ for 23 seconds
(LightCycler 480, Roche Applied Science, Penzberg, Germany). The qPCR mixtures contained $10 \mu \mathrm{L}$ Premix Ex Taq (TaKaRa, Dalian, China), $0.4 \mu \mathrm{L}$ of each primer $(10 \mathrm{pmol} / \mu \mathrm{L}), 0.4 \mu \mathrm{L}$ of probe $(10 \mathrm{pmol} / \mu \mathrm{L}), 2 \mu \mathrm{L}$ of each template DNA, and water in a total volume of $20 \mu \mathrm{L}$ (Wu et al., 2017). All the qPCR experiments were repeated at least three times.

\section{Construction of the standard curve and data analysis}

To assess the efficiency, linear range, and analytical sensitivity of the qPCR, the diluted purified DNA from duck and goose was used to construct separate standard curves (Pegels et al., 2014). DNA was isolated from the meat of domestic duck and Chinese domestic goose individually by the combination of PB and MA. The initial concentration of the two kinds of DNAs was standardized to $20 \mathrm{ng} / \mu \mathrm{L}$, from which a serial dilution was carried out (dilution factor 1:4). After diluting by water, seven concentrations $(20,5,1.3,0.3,0.08,0.02,0.005$ and $0.0001 \mathrm{ng} / \mu \mathrm{L}$ ) were prepared for duck and goose DNAs. Primer efficiencies were calculated using standard curves. The efficiencies for duck and goose were 1.588 and 1.612, respectively.

The amount of target DNA in an unknown sample was then measured by extrapolation of the threshold cycle (Ct) value obtained in the unknown sample in the corresponding standard curve of $\mathrm{Ct}$ values generated from known DNA percentages of the target species. The correlation between the variables, $\mathrm{Ct}$, and concentration ([]) is semilogarithmic:

$\mathrm{Ct}=\mathrm{b} * \log$ [DNA concentration] $+\mathrm{a}$

Where, $b$ is the slope and a denotes the intercept (Pegels et al., 2014).

The linearity of the model was verified by regression analysis (ANOVA). In the coefficient of correlation, $r$, expresses statistically the correlation between test results obtained (Ct values) and DNA concentration in the serial dilution, whereas the coefficient of determination, r2, indicates the correlation quantitatively (Pegels et al., 2014).

Table 1. Primers and probes for detection of duck, goose, and chicken by qPCR.

\begin{tabular}{|c|c|c|c|}
\hline Target species & Nucleotide sequence (5'-3') and fluorescent label & Amplicon size (bp) & Reference \\
\hline $\begin{array}{l}\text { Domestic duck (Anas platyrhynchos and } \\
\text { Anas poecilorhyncha) }\end{array}$ & $\begin{array}{l}\text { F: GGCCACACAAATCCTCACAG } \\
\text { R: TGTGTTGGCTACTGAGGAGAAA } \\
\text { P: FAM-CCTACTGGCTATGCACTACACCGCAGAC-Eclipse }\end{array}$ & 85 & \multirow{3}{*}{$\begin{array}{l}\text { SB/T 10923- } \\
2012(2013)\end{array}$} \\
\hline $\begin{array}{l}\text { Chinese domestic goose and European } \\
\text { domestic goose (Anser cygnoides and } \\
\text { Anser anser) }\end{array}$ & $\begin{array}{l}\text { F: }{ }^{b} \text { GACAATCCAACCTTAACCCGA } \\
\text { R: GGACTAGGGTGATTCCTGCA } \\
\text { P: FAM-CCATCCACTTCCTR }{ }^{\mathrm{c}} \text { CTGCCCTTCCTA-Eclipse }\end{array}$ & 77 & \\
\hline $\begin{array}{l}\text { Domestic chicken (Gallus gallus } \\
\text { domesticus) }\end{array}$ & $\begin{array}{l}\text { F: CGACAACCCAACCCTTACC } \\
\text { R: AGGAAGGTGAGGTGGATGATA } \\
\text { P: FAM-ACACTTCCTCCTCCCCTTTGCAATCGC-Eclipse }\end{array}$ & 89 & \\
\hline
\end{tabular}

F: Forward primer, R: Reverse primer, P: Probe, bp: Base pair, ${ }^{\mathrm{bc}}$ Modifying the original base A into $\mathrm{R}$ 


\section{RESULTS}

\section{Comparison of different preprocessing}

The DNA extracted with PA (treated by shear only) was very low in concentration, about $2.0 \mathrm{ng} / \mu \mathrm{L}$, and also poor in purity, with the value of $\mathrm{A}_{260 / 280}$ between 2.4 and 3 (Table 2). After pretreated with magnetic bead grinding (PB) or liquid nitrogen grinding (PC), the DNA concentration increased to about $4 \mathrm{ng} / \mu \mathrm{L}$, while the values of $\mathrm{A}_{260 / 280}$ were between 1.5 and 2.3, better than PA. Synchronizing liquid nitrogen and physical grinding treatments, the PD process greatly increased the DNA concentration to more than $20 \mathrm{ng} / \mu \mathrm{L}$, and the DNA was of higher purity $\left(\mathrm{A}_{260 / 280}=1.6\right.$ to 2.1$)$ than other treatments (Table 2).

For $\mathrm{PA}, \mathrm{PB}$, and $\mathrm{PC}$, the results of $\mathrm{qPCR}$ were consistent with the purity and quantity of the DNA (Table 2). As long as the concentration and purity of the DNA were low, the corresponding $\mathrm{Ct}$ value was high; otherwise, it was relatively low. For the same sample, the corresponding $\mathrm{Ct}$ value gradually decreased for pretreated with PA, PB, and PC, especially in duck-species detection for the sample of Beijing white duck and Polish white duck, where the Ct of PA was about 37, the $\mathrm{Ct}$ of PB and $\mathrm{PC}$ ranged 31.1-32.5. When in goose-species detection for Northeast white goose, the Ct of PA was up to 37.7, but if it was pretreated by $\mathrm{PB}$ or $\mathrm{PC}$, the $\mathrm{Ct}$ dropped to around 30; which fully demonstrated the importance of the purity and quantity of DNA for PCR detection. However, for the PD method, it was different. Though the DNA concentration was significantly higher than that of others, and the DNA purity was also pretty good (Table 2), the qPCR results were out of expectation, where no positive result was obtained in detecting duck species, but only the $\mathrm{Ct}$ value of goose detection was better than that of other methods.

According to the quality of the DNA, the results of qPCR, and the convenience of operation, $\mathrm{PB}$ was chosen as a unified preprocessing way in the following experiments for comparison of different DNA extraction methods (MA, MB, and MC), unless noted otherwise.

In addition, based on the results of species-specific identification by qPCR (Table 2), it was found that no positive results were obtained when detecting chicken DNA in either duck down or goose down, and for the samples of duck down, the positive signals were only observed in the duck-specific test. However, for goose down samples, both goose and duck-derived DNA were detected, but the content of the duck was lower with the $\mathrm{Ct}$ value close to 35 .

\section{Comparison of different DNA isolation methods}

With the same pretreatment, the efficiency of different DNA extraction methods was compared and the DNA concentration and purity obtained with each method were presented in Table 3. MA yielded the lowest amounts of DNA, with concentrations between $3.1 \mathrm{ng} / \mu \mathrm{L}$ to 4.6 $\mathrm{ng} / \mu \mathrm{L}$. MB increased the concentration up to $13.4 \mathrm{ng} / \mu \mathrm{L}$, and the DNA was of higher purity, with the $\mathrm{A}_{260 / 280}$ values closer to 1.8. DNA obtained by MC was of the largest amount, with the concentrations ranging from $153.4 \mathrm{ng} / \mu \mathrm{L}$ to $188.2 \mathrm{ng} / \mu \mathrm{L}$, but due to the lack of purification processing steps, the purity was quite lower $\left(\mathrm{A}_{260 / 280}=1.1\right.$ to 1.2 ).

In the downstream fluorescence qPCR test, it was confirmed that for the quality of DNA, purity was as important as concentration. Although the concentration of DNA obtained by MC was high, the Ct values were not superior to the corresponding ones of MA and MB. For the same sample, the $\mathrm{Ct}$ values of MB in Table 3 were always the lowest, and the values of MC were always the highest; and for all the three samples, the values of MA in Table 3 were close to the corresponding ones in Table 2, around 30 , which indicates that the performance of the method was stable. The species detection results presented in Table 3 were in accordance with the ones in Table 2. In the duck down, only duck DNA was detected, however, in the goose down, not only goose DNA but also duck DNA were detected. Furthermore, the $\mathrm{Ct}$ value of the duck detection in the goose down lowered to 30.1 .

Based on the above-mentioned results, it was suggested that the extraction methods have more influence on the DNA isolation efficiency than the preprocessing methods. Therefore, to simplify the operation, two new combinations, $\mathrm{PA}+\mathrm{MB}$ and $\mathrm{PA}+\mathrm{MC}$, were tested, in which before DNA extraction, the down was only cut to small pieces by scissors. The results of the DNA quality are shown in Table 4. Considering DNA concentration and the value of $\mathrm{A}_{260 / 280}$, the combinations of $\mathrm{PA}+\mathrm{MB}$ and $\mathrm{PA}$ $+\mathrm{MC}$ (Table 4) were not as effective as the combinations of $\mathrm{PB}+\mathrm{MB}$ and $\mathrm{PB}+\mathrm{MC}$ (Table 3 ) in extraction DNA from the down. However, the results of the detection of species (Table 4) showed that the quality of DNA isolated by $\mathrm{PA}+\mathrm{MB}$ and $\mathrm{PA}+\mathrm{MC}$ can meet the requirements of qPCR detection. Unexpectedly, the $\mathrm{Ct}$ values of the combination of PA + MC (Table 4) were lower than the corresponding values of $\mathrm{PB}+\mathrm{MC}$ (Table 3 ) and $\mathrm{PA}+\mathrm{MB}$ (Table 4) but close to that of $\mathrm{PB}+\mathrm{MB}$ (Table 3). According to these results, the combination of $\mathrm{PA}+\mathrm{MC}$ was considered a simple and effective way to obtain DNA 
from the down; therefore, in the following experiments,

DNA of down was extracted by this combination.

Table 2. Effects of different pretreatment methods on the quality of DNA extracted from down samples

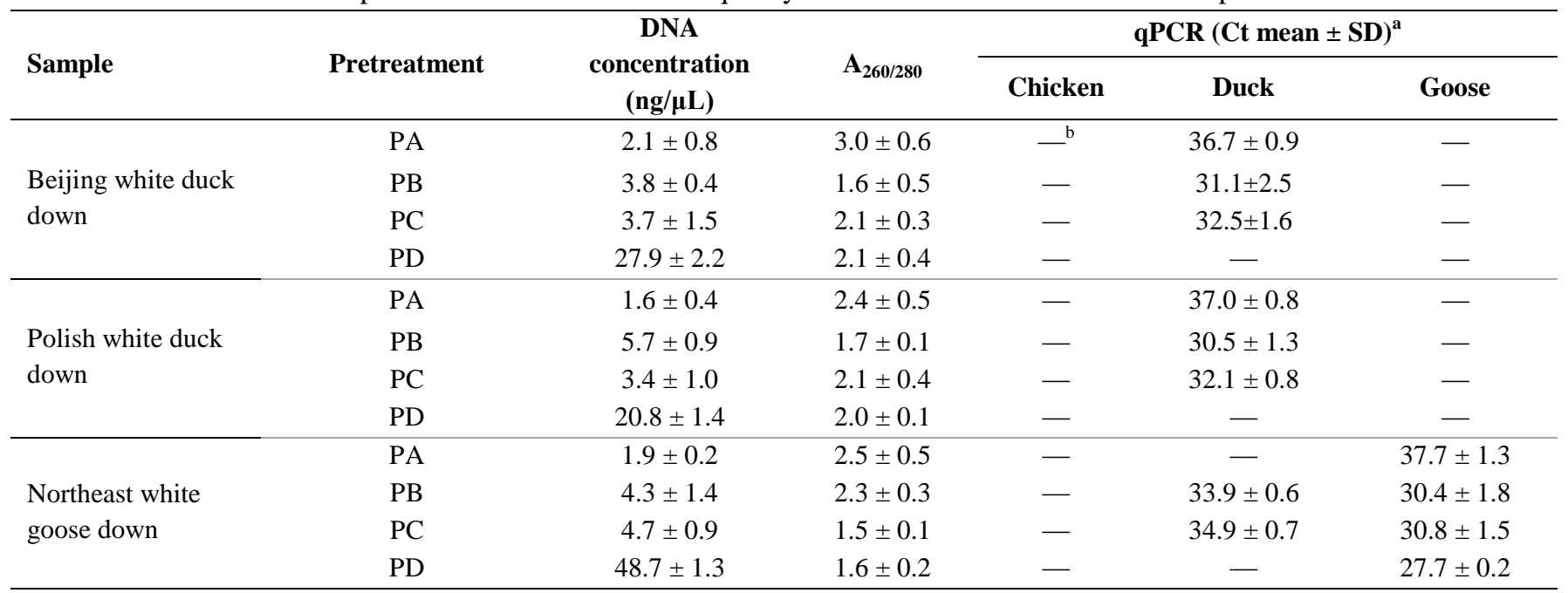

qPCR: Quantitative real-time PCR, Ct: Threshold cycle, SD: Standard deviation. PA: Shredding, PB: Shredding + magnetic bead homogenization, PC: Shredding + manually grinding in liquid nitrogen, PD: Shredding + grinding by 6875 Freezer. In the experiments, DNA was all extracted by the MA method (a magnetic bead adsorption method). ${ }^{a}$ Average Ct value \pm SD shown from triplicate PCR reactions from each DNA extraction. ${ }^{b}$ Not detected (no positive signal after 40 PCR cycles).

Table 3. Effects of different DNA extraction methods on the quality of DNA extracted from down samples

\begin{tabular}{|c|c|c|c|c|c|c|}
\hline \multirow{2}{*}{ Sample } & \multirow{2}{*}{$\begin{array}{l}\text { Extraction } \\
\text { method }\end{array}$} & \multirow{2}{*}{$\begin{array}{c}\text { DNA } \\
\text { concentration } \\
(\mathrm{ng} / \mu \mathrm{L})\end{array}$} & \multirow{2}{*}{$\mathbf{A}_{260 / 280}$} & \multicolumn{3}{|c|}{ qPCR $(\mathrm{Ct} \text { mean } \pm \mathrm{SD})^{\mathrm{a}}$} \\
\hline & & & & Chicken & Duck & Goose \\
\hline \multirow{2}{*}{$\begin{array}{l}\text { Beijing white duck } \\
\text { down }\end{array}$} & MA & $3.1 \pm 1.1$ & $2.0 \pm 0.6$ & $-\mathrm{b}$ & $31 \pm 1.6$ & - \\
\hline & $\mathrm{MC}$ & $153.4 \pm 23.2$ & $1.1 \pm 0.3$ & - & $32.4 \pm 2.5$ & - \\
\hline $\begin{array}{l}\text { Polish white duck } \\
\text { down }\end{array}$ & MA & $4.8 \pm 1.4$ & $1.9 \pm 0.5$ & - & $29.2 \pm 0.8$ & - \\
\hline \multirow{3}{*}{$\begin{array}{l}\text { Northeast white goose } \\
\text { down }\end{array}$} & MA & $4.6 \pm 0.8$ & $1.5 \pm 0.6$ & - & $32.9 \pm 1.4$ & $30.3 \pm 0.2$ \\
\hline & MB & $10.7 \pm 1.9$ & $1.7 \pm 0.4$ & - & $30.1 \pm 0.8$ & $25.3 \pm 1.3$ \\
\hline & $\mathrm{MC}$ & $188.2 \pm 46.8$ & $1.1 \pm 0.2$ & - & $34.1 \pm 1.8$ & $31.3 \pm 2.7$ \\
\hline
\end{tabular}

qPCR: Quantitative real-time PCR, Ct: Threshold cycle, SD: Standard deviation. All the samples were pretreated by PB (shredding + magnetic bead homogenization). MA: a magnetic bead adsorption method; MB: a membrane adsorption-elution method; MC: a Chelex® $100 \mathrm{Resin}$ method. ${ }^{\mathrm{a}} \mathrm{Average} \mathrm{Ct}$ value \pm SD shown from triplicate PCR reactions from each DNA extraction. ${ }^{b}$ Not detected (no positive signal after 40 PCR cycles).

Table 4. Effects of combinations of PA $+\mathrm{MB}$ and PA + MC on the quality of DNA extracted from down samples

\begin{tabular}{|c|c|c|c|c|c|c|}
\hline \multirow{2}{*}{ Sample } & \multirow{2}{*}{ Methods } & \multirow{2}{*}{$\begin{array}{c}\text { DNA } \\
\text { concentration } \\
(\mathrm{ng} / \mu \mathrm{L})\end{array}$} & \multirow{2}{*}{$\mathbf{A}_{260 / 280}$} & \multicolumn{3}{|c|}{ qPCR $(\mathrm{Ct} \text { mean } \pm \mathrm{SD})^{\mathrm{a}}$} \\
\hline & & & & Chicken & Duck & Goose \\
\hline $\begin{array}{l}\text { Beijing white duck } \\
\text { down }\end{array}$ & $\mathrm{PA}+\mathrm{MB}$ & $6.4 \pm 2.1$ & $2.1 \pm 0.4$ & $-^{b}$ & $26.5 \pm 0.8$ & - \\
\hline \multirow{2}{*}{$\begin{array}{l}\text { Polish white duck } \\
\text { down }\end{array}$} & $\mathrm{PA}+\mathrm{MB}$ & $9.1 \pm 1.5$ & $2.4 \pm 0.6$ & - & $27.4 \pm 2.4$ & - \\
\hline & $\mathrm{PA}+\mathrm{MC}$ & $89.4 \pm 16.5$ & $1.2 \pm 0.1$ & - & $25.1 \pm 1.1$ & - \\
\hline
\end{tabular}

qPCR: Quantitative real-time PCR, Ct: Threshold cycle, SD: Standard deviation. All the samples were pretreated by PA. PA: Shredding, MB: A membrane adsorption-elution method, MC: A Chelex® 100 Resin method. ${ }^{a}$ Average Ct value \pm SD shown from triplicate PCR reactions from each DNA extraction, ${ }^{b}$ Not detected (no positive signal after 40 PCR cycles) 


\section{Species detection for eleven samples}

By the combination of PA + MC, DNA of 11 down samples were extracted. The concentrations of the DNA were high, all more than $70 \mathrm{ng} / \mu \mathrm{L}$, but the purities were low, none of the values of $\mathrm{A}_{260 / 280}$ higher than 1.5. However, the $\mathrm{Ct}$ values of the target species detection for the 11 samples ranged from 25.7 to 33.7 , indicating that the quality of the DNA can meet the needs of qPCR detection. The species detection of the 11 samples showed that no chicken DNA was detected in all the samples; in 8 ducks down samples, only duck DNA was detected; and in 1 duck down and 2 goose down samples, both duck and goose DNA were detected. Detection of duck down from goose down is usually suspected of adulteration, if the amount of duck down greatly exceeds the labeled amount. Conversely, detection of goose down from duck down might be due to unintended cross-contamination.

\section{Duck and goose standard curve and determination of mixing ratios \\ Eight 4-fold dilution series of duke and goose DNA} starting from $20 \mathrm{ng} / \mu \mathrm{L}$ were prepared for the construction of standard curves in qPCR. Considering $2 \mu \mathrm{L}$ template DNA used in each qPCR mixture, the detection limits for duck and goose specific PCR were both $0.01 \mathrm{ng}$ (Table 1, Figure 1). To test the linearity, $\mathrm{Ct}$ values were plotted versus the logarithm of the DNA concentrations (Figure 1 ). The coefficient values ( $r^{2}$ values) of duck- and goosespecific standard curves were 0.9834 and 0.9806 , respectively, which indicated $98.34 \%$ and $98.06 \%$ of the variations in $\mathrm{Ct}$ values, individually in Figure1a and figure $1 \mathrm{~B}$, can be attributed to the variations in the logarithm of DNA concentrations.
According to a certain proportion (Table 6), the mixed samples of Polish white duck down and Northeast white goose down were prepared. The DNA extracted from the binary mixtures was detected by duck and goose-specific qPCRs, respectively. Based on the $\mathrm{Ct}$ values of the fluorescent PCR tests and the standard curves in figure 1, DNA concentrations of duck and goose in the mixtures were calculated. Furthermore, 3.7\%, 10.9\%, 20.6\%, $31.6 \%, 43.9 \%$, and $56.6 \%$ proportions of duck component were calculated in the six samples with an initial theoretical proportion of $0,10 \%, 20 \%, 30 \%, 40 \%$ and $50 \%$, respectively. The Northeast white goose down used in this study was $90 \%$ down meaning that at least $90 \%$ of the ingredients in the down were goose down clusters and goose down fibers, and the remaining $10 \%$ might be the goose feather, the other waterfowl or landfowl feather, or feather fibers. Assuming that $3.7 \%$ duck component in $100 \%$ goose down was true, the theoretical values of the $10-50 \%$ duck mass percentage needed to be adjusted. The original contents $10 \%$ and $20 \%$ should be adjusted to $13.3 \%([10+90 * 0.037] * 100 \%=13.3 \%)$ and $22.9 \%$ $([20+80 * 0.037] * 100 \%=22.9 \%)$, respectively, and the other values in the same column could be calculated in the same way. When the proportion of duck down was between $30 \%$ and $40 \%$, the calculated values were relatively close to the corresponding adjusted theoretical values, with the gaps of $3.1 \%$ and $4.0 \%$. But when the duck down content was less than $30 \%$ or greater than $40 \%$, the difference between the two corresponding values increased. Based on the calculation method, it was found that the proportions of duck down in the white goose down and Grey goose down in Table 5 were as high as $9.5 \%$ and $6.3 \%$, respectively.

Table 5. Detection of goose, duck, and chicken species in 11 down samples by qPCR

\begin{tabular}{|c|c|c|c|c|c|}
\hline \multirow{2}{*}{ Sample } & \multirow{2}{*}{$\begin{array}{c}\text { DNA concentration } \\
(\mathrm{ng} / \mu \mathrm{L})\end{array}$} & \multirow{2}{*}{$\mathbf{A}_{260 / 280}$} & \multicolumn{3}{|c|}{ qPCR $(\mathrm{Ct} \text { mean } \pm \mathrm{SD})^{\mathrm{a}}$} \\
\hline & & & Chicken & Duck & Goose \\
\hline Anhui white duck down 352 & $109.8 \pm 33.8$ & $1.3 \pm 0.3$ & - & $25.7 \pm 2.1$ & - \\
\hline Guangxi Guigang white duck down & $86.9 \pm 13.3$ & $1.4 \pm 0.3$ & - & $28.4 \pm 2.8$ & $33.2 \pm 2.8$ \\
\hline Grey duck down 362 & $117 \pm 23.7$ & $1.2 \pm 0.1$ & - & $30.4 \pm 2.6$ & - \\
\hline Lu'an grey duck down 309 & $94.4 \pm 22.6$ & $1.4 \pm 0.2$ & - & $29.8 \pm 1.3$ & - \\
\hline Guangdong grey duck down & $118.4 \pm 34.1$ & $1.3 \pm 0.2$ & - & $28.6 \pm 1.7$ & - \\
\hline White goose down & $73.2 \pm 23.0$ & $1.4 \pm 0.3$ & - & $31.1 \pm 2.1$ & $27.3 \pm 1.6$ \\
\hline Grey goose down & $100.4 \pm 19.3$ & $1.4 \pm 0.4$ & - & $33.7 \pm 1.3$ & $28.9 \pm 2.4$ \\
\hline
\end{tabular}

qPCR: Quantitative real-time PCR, Ct: Threshold cycle, SD: Standard deviation. DNA was extracted by the combination of PA (shredding) + MC (a Chelex ${ }^{\circledR} 100$ Resin method). ${ }^{a}$ Average Ct value \pm SD shown from triplicate PCR reactions from each DNA extraction; ${ }^{b}$ Not detected (no positive signal after 40 PCR cycles). 
Table 6. Calculation for duck down percentage in six mixed duck-goose down samples

\begin{tabular}{|c|c|c|c|c|c|c|c|c|}
\hline \multicolumn{2}{|r|}{ Sample } & \multicolumn{2}{|c|}{ Duck } & \multicolumn{2}{|c|}{ Goose } & \multirow[b]{2}{*}{$\begin{array}{l}\text { Percentage of } \\
\text { duck down by } \\
\text { calculation }^{b}\end{array}$} & \multirow{2}{*}{$\begin{array}{c}\text { Adjusted } \\
\text { percentage of } \\
\text { duck down in } \\
\text { theory }\end{array}$} & \multirow[b]{2}{*}{$\begin{array}{l}{[(b-c)} \\
/ c] \times 100^{c}\end{array}$} \\
\hline No. & $\begin{array}{c}\text { Percentage of } \\
\text { duck down in } \\
\text { theory }\end{array}$ & Ct value ${ }^{a}$ & $\begin{array}{c}\text { DNA } \\
\text { concentration } \\
(\mathrm{ng} / \mu \mathrm{L})\end{array}$ & Ct value ${ }^{\mathrm{a}}$ & $\begin{array}{c}\text { DNA } \\
\text { concentration } \\
(\mathrm{ng} / \mu \mathrm{L})\end{array}$ & & & \\
\hline 1 & $0 \%$ & 29.8 & 0.081 & 23.9 & 2.12 & $3.7 \%$ & $3.7 \%$ & -- \\
\hline 2 & $10 \%$ & 28.1 & 0.18 & 24.7 & 1.45 & $10.9 \%$ & $13.3 \%$ & $-18.0 \%$ \\
\hline 3 & $20 \%$ & 27.1 & 0.28 & 25.3 & 1.08 & $20.6 \%$ & $22.9 \%$ & $-10.0 \%$ \\
\hline 4 & $30 \%$ & 26.9 & 0.31 & 26.3 & 0.67 & $31.6 \%$ & $32.6 \%$ & $-3.1 \%$ \\
\hline 5 & $40 \%$ & 26.6 & 0.36 & 27.1 & 0.46 & $43.9 \%$ & $42.2 \%$ & $4.0 \%$ \\
\hline 6 & $50 \%$ & 26.0 & 0.47 & 27.6 & 0.36 & $56.6 \%$ & $51.9 \%$ & $9.1 \%$ \\
\hline
\end{tabular}

Ct: Threshold cycle, ${ }^{a}$ Mean value of three results, ${ }^{b}$ According to the concentrations of duck and goose, ${ }^{c}$ Difference between the calculated value and the adjusted value in theory
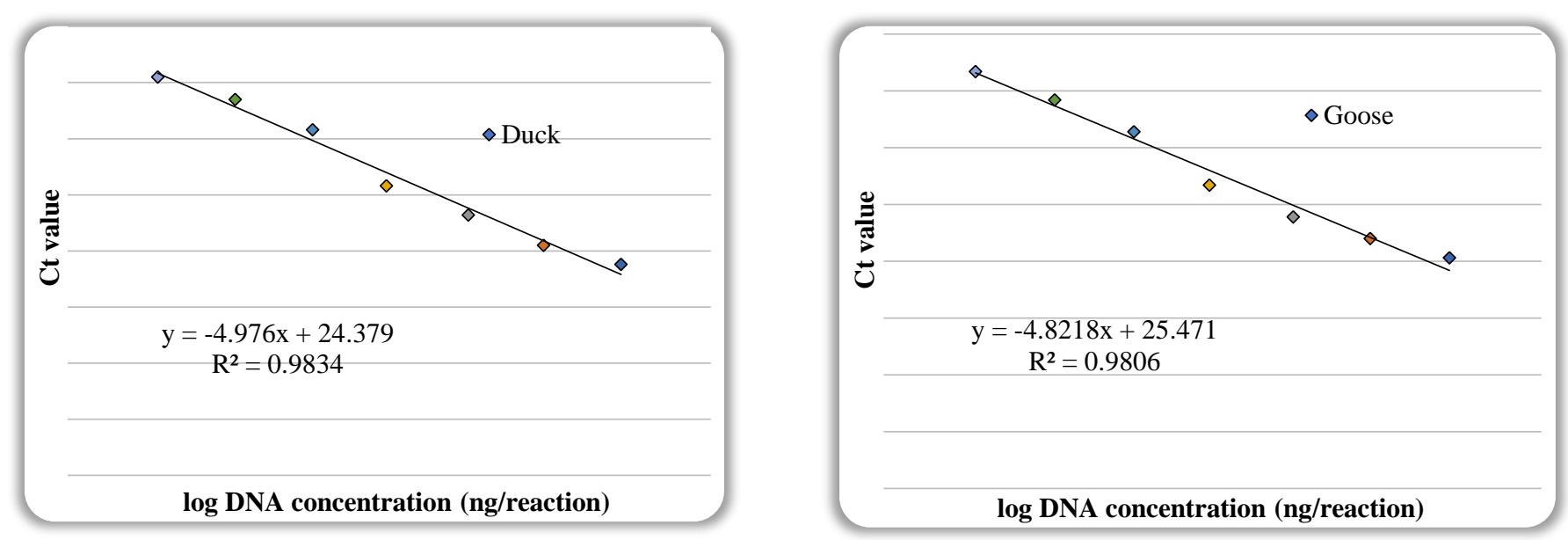

Figure 1. Amplification curve of DNA concentrations against the cycle threshold $(\mathrm{Ct})$ values. A: For detection of duck; B: For detection of goose

\section{DISCUSSION}

DNA of sufficient yield and quality is the crucial starting material for molecular analyses. For this goal, four pretreatments and three DNA extraction methods were assessed. In the pretreatment process, except for PD, other treatments could do little to improve the concentration and purity of DNA. However, in addition to the quantity and purity of the template, the integrity of the DNA, and the presence or absence of inhibitors, all of these can affect subsequent PCR amplification. Therefore, although yielding the largest amounts of DNA and the DNA of higher purity, PD treatment, on the contrary, led to a decrease in the detection rate in avian-specific qPCR assay. Then, for confirmation, PD was repeated three more times, but the corresponding qPCR detection rate was still low, with 3 positive results out of 12 tests (data have not been shown). The PD treatment made all down samples into a fine powder, which facilitated the release of DNA from the cell, meanwhile broke the long strand DNA into small fragments. As a result, despite the high concentration and purity of the template and the short length of the PCR amplicons (Table 1), the primer pairs still failed to amplify the target fragments. Physical grinding in pretreatment, even with the supporting equipment, was labor-intensive and time-consuming, and compared with the extraction process, the pretreatment process had little effect on improving DNA quality. Therefore, except for the shredding step, other pretreatment operations were omitted.

Chen et al. (2013) extracted DNA by SDS-agmatine thiocyanate- $\beta$-mercaptoethanol method at a concentration between $20 \mathrm{ng}$ to $200 \mathrm{ng}$, which is similar to the DNA concentration obtained in this study. DNA in animal fiber mainly exists in the hair follicle part, and there is a small amount of mitochondrial DNA in the hair shaft. Since then, Chen et al. (2013) only chose the down with hair follicle for the experiment, and only the hair follicle part in the sample was used to extract DNA. In the present research, the whole down was used for DNA extraction, and regardless of whether it had a hair follicle or not. However, the randomness in sampling simplifies the 
operation and is more in line with the needs of practical detection.

In addition to easy and rapid performance and inexpensive, an optimal DNA preparation method for routine testing should also avoid the use of hazardous chemicals (Tomasek et al., 2008). In this study, two kit methods and Chelex ${ }^{\circledR} 100$ Resin were chosen and evaluated. Compared with the kits, Chelex ${ }^{\circledR} 100$ Resin treatment was easy for operation and yielded the largest amounts, but lowest purity of DNA (Table 3 and 4); nevertheless, the template DNA could satisfy the following qPCR detection. Similarly, Tomasek et al. (2008) also considered Chelex ${ }^{\circledR} 100$ Resin the best option for extracting virus DNA from avian feathers when compared with NucleoSpin ${ }^{\circledR}$ Tissue Kit and DNAzol ${ }^{\circledR}$ Direct kit methods. Here, according to the results, the combination of PA + MC was the best way to extract DNA from down.

The common goose down mainly comes from Chinese domestic goose and European domestic goose. Therefore, to enable to cover the two geese, the primer and probe sequences in the original standard were modified (Table 1). The copy numbers of the mitochondrion in muscle and down may be different, but due to the lack of $100 \%$ goose down, two standard curves were made by the DNA extracted from the meat of duck and goose. However, the duck down percentages of the binary mixtures calculated based on the standard curves were approximately close to the pre-set values (Table 6). In real-time PCR assay, in addition to DNA concentration, $\mathrm{Ct}$ value may also reflect the quality of DNA purity. DNA extracted from down by the combination of PA + MC might be lower in purity and higher in $\mathrm{Ct}$ value, which may lead to a deviation when measuring DNA concentration using the standard curve established with the DNA extracted from meat by the method of PB + MA. But instead of the absolute DNA concentration, the final value is a ratio of concentration, so the deviation can be eliminated.

\section{CONCLUSION}

This preliminary study demonstrated the potential application of qPCR for the identification of goose, duck, or chick down. This method can be used as an auxiliary method, especially, when morphological detection is difficult, such as using the young duck's down as goose down.

\section{DECLARATIONS}

\section{Acknowledgments}

This work was supported by grants from the Research Project of the General Administration of Customs P.R. China (2020HK157), the National Key Research and Development Program of China (No. 2017YFF0210304), and the Key Research and Development Program of Zhejiang Province (No. 2018C02041).

\section{Authors' contributions}

Shan $\mathrm{Wu}$ and Xiaofeng Zhang designed the research; Huizhen Yu, Yongqiang He, Mingzhe Zhang, Wenxiu Yin, Quan Zhang, Chao Sun, Zhe Chen, and Xufang Shen performed the research and analyzed the data; Shan Wu wrote the manuscript; Xiaofeng Zhang and Huizhen $\mathrm{Yu}$ have taken part in the revision of the manuscript. All authors read and approved the final version of the manuscript.

\section{Competing interests}

The authors declare that they have no competing interests.

\section{Ethical considerations}

Authors have checked ethical issues (including plagiarism, consent to publish, misconduct, data fabrication and/or falsification, double publication and/or submission, and redundancy).

\section{REFERENCES}

Alberts CC, Ribeiro-Paes JT, Aranda-Selverio G, Cursino-Santos JR, Moreno-Cotulio VR, Oliveira AL, Porchia BF, Santos WF, and Souza EB (2010). DNA extraction from hair shafts of wild Brazilian felids and canids. Genetics and Molecular Research, 9(4): 2429-2435. DOI: https://www.doi.org/10.4238/vol9-4gmr1027

Bello N, Francino O, and Sanchez A (2001). Isolation of genomic DNA from feathers. The Journal of Veterinary Diagnostic Investigation, 13: 162-164. DOI: https://www.doi.org/10.1177/104063870101300212

Boonseub S, Johnston G, and Linacre A (2012). Identification of protected avian species using a single feather barb. Journal of Forensic Sciences, 57(6): 1574-1577. DOI: https://www.doi.org/10.1111/j.1556-4029.2012.02206.x

BS-EN-12131: 2018 (2018). European Committee for Standardization. Determination of the quantitative composition of feather and down (manual method). BSI Standards Limited. Available at: http://www.doc $88 . c o m / p-$ 6711715113798.html

Chen GP, Lai XT, Tang FR, Lin L, Yang YH, Yang ZM, and Yang GW (2013). Real-time PCR identification of duck and goose down fiber products. China Fiber Inspection, 12: 6062. DOI: https://www.doi.org/10.3969/j.issn.16714466.2013.23.024 
FZ/T 80001-2002 (2002). Testing method for washed feather and down. National Economic and Trade Commission of the People's Republic of China. Standards Press of China (in Chinese). Available at: https://max.book118.com/html/2019/0608/60101241100020 35.shtm

GB/T 10288-2016 (2016). Test method for down and feather. Certification and Accreditation Administration of the People's Republic of China. Standards Press of China, 2016. (in Chinese). Available at: https://www.sohu.com/a/154729002_660740

Grisedale KS, Murphy GM, Brown H, Wilson MR, and Sinha SK (2018). Successful nuclear DNA profiling of rootless hair shafts: A novel approach. International Journal of Legal Medicine, 132(1): 107-115. DOI: https://www.doi.org/10.1007/s00414-017-1698-z

Haines AM, and Linacre A (2016). A rapid screening method using DNA binding dyes to determine whether hair follicles have sufficient DNA for successful profiling. Forensic Science International, 262: 190-195. DOI: https://www.doi.org/10.1016/j.forsciint.2016.03.026

Henry P, and Russello AM (2011). Obtaining high-quality DNA from elusive small mammals using low-tech hair snares. South African Journal of Wildlife Research, 57: 429-435. DOI: https://www.doi.org/10.1007/s10344-010-0449-y

Malagó W Jr, Franco HM, Matheucci E Jr, Medaglia A, and Henrique-Silva F (2002). Large scale sex typing of ostriches using DNA extracted from feathers. BMC Biotechnology, 2: 19. DOI: https://www.doi.org/10.1186/1472-6750-2-19

SB/T 10923-2012 (2013). Species identification of animal derived materials in meat and meat products-real-time PCR method. Ministry of Commerce of the People's Republic of China. Standards Press of China (in Chinese). Available at: https://max.book118.com/html/2018/1020/70200351400011 $\underline{53 . s h t m}$

Pegels N, González I, García T, and Martín R (2014). Avianspecific real-time PCR assay for authenticity control in farm animal feeds and pet foods. Food Chemistry, 142: 39-47. DOI: https://www.doi.org/10.1016/j.foodchem.2013.07.031

Presti FT, Meyer J, Antas PT, Guedes NM, and Miyaki CY (2013). Non-invasive genetic sampling for molecular sexing and microsatellite genotyping of hyacinth macaw (Anodorhynchushyacinthinus). Genetics and Molecular Biology, 36(1): 129-133. DOI: https://www.doi.org/10.1590/S1415-47572013005000001

Speller CF, Nicholas GP, and Yang DY (2011). Feather barbs as a good source of mtDNA for bird species identification in forensic wildlife investigations. Investigative Genetics, 2: 16-23. DOI: https://www.doi.org/10.1186/2041-2223-2-16

Subramanian S, Karthik T, and Vijayaraaghavan NN (2005). Single nucleotide polymorphism for animal fibre identification. Journal of Biotechnology, 116(2): 153-158. DOI: https://www.doi.org/10.1016/j.jbiotec.2004.10.015

Tomasek O, Kubicek O, and Tukac V (2008). Comparison of three template preparation methods for routine detection of beak and feather disease virus and avian polyomavirus with single and nested polymerase chain reaction in clinical specimens. Avian Pathology, 37(2): 145-149. DOI: https://www.doi.org/10.1080/03079450801902047

Wu S, He YQ, Lu XM, Zhang XF, Shuai JB, Yu HZ, Jin CC, and Mo HF (2017). Early and simultaneous detection of Nosema bombycis, nucleopolyhedrovirus and densovirus by multiplex real-time PCR in Bombyx mori. The Canadian Entomologist, $149(2)$ : 265-275. DOI: https://www.doi.org/10.4039/tce.2016.54 